
\title{
28 Research Square \\ Two Shades of Grey: Effect of Temperature on Seed Germination of the Escaping Ornamental Species Lychnis Coronaria and Stachys Byzantina
}

\section{Martin Vojík ( $\nabla$ vojik@fzp.czu.cz)}

Faculty of Environmental Sciences, Czech University of Life Sciences in Prague https://orcid.org/00000001-9735-5120

\section{Martina Kadlecová}

Czech University of Life Sciences Prague Faculty of Environmental Sciences: Ceska Zemedelska Univerzita v Praze Fakulta Zivotniho Prostredi

Josef Kutlvašr

Czech University of Life Sciences Prague Faculty of Environmental Sciences: Ceska Zemedelska Univerzita v Praze Fakulta Zivotniho Prostredi

Jan Pergl

Institute of Botany Czech Academy of Sciences: Botanicky Ustav Akademie Ved Ceske Republiky Kateřina Berchová Bímová

Czech University of Life Sciences Prague Faculty of Environmental Sciences: Ceska Zemedelska Univerzita v Praze Fakulta Zivotniho Prostredi

\section{Research Article}

Keywords: alien species, generative reproduction, genome size, Lamb's ear, ornamental plants, Rose campion

Posted Date: January 12th, 2022

DOI: https://doi.org/10.21203/rs.3.rs-1211843/v1

License: (c) (1) This work is licensed under a Creative Commons Attribution 4.0 International License. Read Full License 


\section{Abstract}

This paper describes germination and cytological variability in two popular ornamental and potentially invasive species, lamb's ear Stachys byzantina and rose campion Lychnis coronaria. Both xerophytic species have the potential to invade natural habitats across Europe and create viable naturalised populations, with subsequent impacts on native vegetation. To assess the species' invasiveness, seeds were collected from naturalised populations and germination rate recorded under different temperature regimes. Flow cytometry, used to record cytological variability, indicated that all populations of both species were cytologically homogeneous. Germination success, a key spreading factor in both species, was significantly influenced by temperature, with final germination of $L$. coronaria being extremely high at temperatures $>15 / 10{ }^{\circ} \mathrm{C}(98.5 \%)$ and extremely low at temperatures $<10 / 5^{\circ} \mathrm{C}(2.9 \%)$. In comparison, final germination in S. byzantina highest at $22 / 15^{\circ} \mathrm{C}(55.6 \%)$, reducing to $40.3 \%$ at $15 / 10{ }^{\circ} \mathrm{C}$ and just $0.3 \%$ at temperatures $<10 / 5^{\circ} \mathrm{C}$. No significant differences in germination rate were observed between escaping and non-escaping populations, though there were differences between particular populations. Our results indicate germination temperature limits between species consistent with sizes of primary distribution and distance between primary and secondary distribution borders. However, the observed germination rates allow for successful generative reproduction of both species over their secondary distribution areas, suggesting that these species are likely to become invasive species of European grasslands soon.

\section{Introduction}

Horticulture has been an integral part of human society for centuries (Relf and Dorn 1995; Zhou 1995; Kendle and Stoneham 2014). Recently, however, the increasing influence of horticulture has made it one of the major sources of alien plant species (Dehnen-Schmutz and Touza 2008; Klonner et al. 2017; van Kleunen et al. 2018; Vojík et al. 2020). These not only contribute significantly to regional floral communities (Köppler et al. 2014; Lososová et al. 2015; Pergl et al. 2016), they potentially threaten biodiversity and natural ecosystems, leading to homogenisation of the Earth's biota (Vilà et al. 2011; Price et al. 2018; Morri et al. 2019; Pyšek et al. 2020). The control and eradication of such 'invasive species' is demanding and often unfeasible (Ewel and Putz 2004; Downey et al. 2010) and, as such, it is crucial to prevent the spread of potentially invasive species before they get a hold (van Kleunen et al. 2007). Whether a species becomes invasive depends not only on the species' ecology but also the physical characteristics of the invaded habitat and the prevalent environmental conditions (Pyšek et al. 2012a). One of the most important ecological traits to assess when investigating the potential for invasion in early spreading species are their reproduction traits, i.e. whether they can be a 'master of all traits' or if they have predominant characteristics leading to their success (Pyšek 2007; Pyšek et al. 2009). Species reproducing by seed tend to be associated with traits such as light availability and temperature regime, with low temperatures limiting germination and short days influencing seedling establishment (Pepe et al. 2020). However, species that are capable of germinating at lower temperatures, with earlier timing of 
germination and rapid seedling growth, will have a competitive advantage over other species (Baskin and Baskin 1998).

Recent studies focused on reproduction traits have often concentrated on variability within the genetic structure of plant populations (e.g. Saad et al. 2011). Introduced populations with high genetic or cytological diversity are likely to adapt rapidly to novel environments and, as such, it represents an important factor influencing their survival capacity (Puillandre et al. 2008; Estoup et al. 2016). If the introduced population is small, however, it may have a low level of variability, creating a bottleneck effect that could limit its invasion success (Puillandre et al. 2008). Nevertheless, some introduced species have become invasive with a low level of genetic/cytological diversity due to a so-called 'genetic paradox of invasion' (Hassan et al. 2003; Dlugosch and Parker 2008b; Estoup et al. 2016), whereby genome size and polyploidy in newly spreading alien species may be the first indication of increasing variability or ongoing evolutionary processes, which could then support invasion (Meyerson et al. 2020; Wan et al. 2020).

Other characteristics aside from reproduction traits have also been identified as significantly affecting invasion/naturalisation probability in ornamental taxa (Pyšek et al. 2019). For example, the horticultural success of certain species is mainly related to their charisma (e.g. colour, shape and size of bloom or time of flowering), which affects not only global public perception but also introduction by humans and resistance to management following their escape (McNeely 2001; Shackleton et al. 2019; Jarić et al. 2020). The invasion potential of ornamental species following introduction will then be linked to their ability to grow under low maintenance (e.g. abandoned sites) and their adaptability to local conditions (e.g. temperature, humidity), such characteristics also giving the species a greater ability to escape from horticulture (Williams et al. 2010; Flory et al. 2011; Vojík et al. 2020; Kutlvašr et al. 2020). There have also been several recent cases of ornamentals spontaneously spreading due to global warming, highlighting their potential to reflect climate change (Dullinger et al. 2017; Haeuser et al. 2018).

In this study, we describe germination and cytological variability in two popular ornamental and potentially invasive species, lamb's ear Stachys byzantina and rose campion Lychnis coronaria, both of which are naturalised in the Czech Republic and have spread into thermophilous human-made habitats. Both species are popular ornamentals worldwide due to their grey-felted leaves and easy maintenance and have been planted in a wide range of habitats, including public parks and private gardens and courtyards (Dimke et al. 2008; Wade 2010; Cullen et al. 2011; Glawe and Koike 2018). Records of both species escaping from cultivation have increased in recent years, with such escapes going on to form viable populations in both artificial and semi-natural habitats (Barošová and Baroš 2009; Kutlvašr et al. 2019; Vojík et al. 2020), including narrow and broad-leaved dry grasslands and acidophilous dry grasslands. Consequently, these species can be considered as newly emerging alien species that could easily become invasive. Moreover, in the case of $S$. byzantina, hybridisation may be possible with an endangered native species, Stachys germanica - Endangered category (C2b) in the IUCN Red List of endangered species (see Grulich 2017), recently recorded in the Czech Republic (Danihelka in prep.). Hybridisation, alongside effective generative reproduction, could significantly accelerate the invasive 
success of $S$. byzantina by producing high performance genotypes that could colonise even unfavourable sites rapidly (see Buhk and Thielsch 2015).

Though both species originate in the Middle East, they differ in their geographical range of primary distribution (POWO 2019). It has been shown repeatedly that the probability of naturalisation success is affected by the size of a species' geographical range and its habitat range niche (e.g. Rejmánek 1996; Pyšek et al. 2009). With a native distribution centred on the Mediterranean and Central Asia, L. coronaria has a sizeable primary distribution with a broad ecological amplitude (Hejný 1997; CABI 2019; Chytrý et al. 2021) unlike S. byzantina, which is an endemic species to Iran (Asnaashari et al. 2010). While the basic descriptive characteristics regarding biology and ecology are known for both species (see Hejný 1997; Chytrý et al. 2021), details on population variability and their ability to spread remain largely unknown.

\section{Study aims}

In order to identify reasons for the recent spread of both species, we undertook a series of tests to assess cytological variability and in vitro seed germination potential. In doing so, we asked a series of questions: (1) How homogenous is their cytological variability? (2) Is the germination rate of either species affected by temperatures? (3) Does germination vary among populations and are there differences between escaping and non-escaping populations? (4) Is there a difference in the generative reproduction temperature limit between species with different ecological niches, size of primary distribution and distance between primary and secondary distribution borders?

\section{Material And Methods}

\section{Study species}

Stachys byzantina C. Koch (Lamiaceae) is a perennial, long-felted, $20-80 \mathrm{~cm}$ tall herb. It is diploid $(2 \mathrm{n}=$ 30; Hejný 1997; Lindqvist and Albert 2017; Wild et al. 2019). Originally an endemic Iranian mountain species (Asnaashari et al. 2010), it has widened its native area to include north Turkey and the Crimean Peninsula (POWO 2019). It has been introduced to Central and Western Europe, North America, Canada and New Zealand (POWO 2019). Germination rates for S. byzantina are not available; however, generative reproduction has been observed in the field (Vojík et al. 2020).

Lychnis coronaria (L.) Desr. (Caryophyllaceae) is a short-lived, white felted, perennial plant, generally grown as a biennial or annual, 30-60 $(-100) \mathrm{cm}$ tall (Jiang et al. 2016). It is diploid $(2 \mathrm{n}=24$; Hejný 1997; Jeelani et al. 2011; Zonneveld 2019). It originates from the Mediterranean, Middle East and the whole of Central Asia. The northern boundary of the species area reaches southern Slovakia. It is non-native in Central and Western Europe and North and South America (Brazil, Chile; Hejný 1997; POWO 2019). The germination rate of $L$. coronaria is $100 \%$ under optimal laboratory conditions, with seedling establishment reaching almost 60\% (Moravcová et al. 2010). 


\section{Population genome size variability}

To assess genome size homogeneity, the DNA weight per nucleus (genome size; expressed in picograms [pg]) was determined for each study population (see Online Resource table) using flow cytometry, based on a two-step procedure using Otto I and II buffers (Otto 1990). As its genome size (2C DNA = $3.38 \mathrm{pg}$ ) is close to that of the species studied, the common daisy Bellis perennis was used as an internal reference standard (Schönswetter et al. 2007). In each case, $1 \mathrm{~cm}^{2}$ of fresh leaf tissue from the study species and from B. perennis were macerated together with a sharp blade and placed in a Petri dish containing $0.1 \mathrm{ml}$ of ice-cold Otto I buffer ( $0.1 \mathrm{M}$ citric acid monohydrate, $0.5 \% \mathrm{v} / \mathrm{v}$ Tween 20$)$ for approx. $90 \mathrm{~s}$, after which the suspension was filtered through a $42 \mu \mathrm{m}$ nylon mesh. Nuclei within the filtered suspension were then stained with $1 \mathrm{ml}$ of Otto II buffer $\left(0.4 \mathrm{M} \mathrm{Na}_{2} \mathrm{HPO}_{4} .12 \mathrm{H}_{2} \mathrm{O}\right)$ supplemented with $1 \mathrm{ml}$ of DAPI stock solution (DAPI $10 \mathrm{mg}$ dissolved in $\left.100 \mathrm{ml} \mathrm{H}_{2} \mathrm{O}\right)+50 \mu \mathrm{l}$ ß-mercaptoethanol $(2 \mu \mathrm{L} / \mathrm{mL}$ ). Each sample was then incubated at room temperature for $10 \mathrm{~min}$ and analysed using a Sysmex-Partec CyFlow SL equipped with a green solid-state laser flow cytometer $(532 \mathrm{~nm}, 100 \mathrm{~mW}$ output power; Sysmex Partec GmbH, Görlitz, Germany).

\section{Seed collection and germination experiments}

Two germination experiments were undertaken, the first assessing the effect of temperature regime on seed germination, and the second assessing differences in germination rate between escaping and nonescaping populations.

To evaluate the effects of temperature regime on seed germination, we collected seeds from fully mature plants of four $L$. coronaria populations and four $S$. byzantina populations from the Czech Republic at the end of the 2017 and 2018 vegetation seasons (see Online Resource table). The seeds were then incubated in Petri dishes on three-layers of filter paper dampened with distilled water. Seeds were kept under a simulated daily light regime consisting of 14 hours light and 10 hours dark with four different temperature regimes, $22 / 15^{\circ} \mathrm{C}, 15 / 10^{\circ} \mathrm{C}, 10 / 5^{\circ} \mathrm{C}$ and $5 / 3^{\circ} \mathrm{C}$. The $5 / 3^{\circ} \mathrm{C}$ regime was only used for $L$. coronaria as a previous study has shown that $S$. byzantina seeds stop germinating at $10 / 5^{\circ} \mathrm{C}$. All germinated seeds were counted and recorded at two-day intervals for 30 days.

To compare differences in germination rate between escaping and non-escaping populations, seeds were collected from mother plants (not escaping daughter plants) growing in garden bed. Eight $S$. byzantina populations were sampled, four escaping and four non-escaping, and six L. coronaria populations, four escaping and two non-escaping (see Online Resource table). Escaping populations were characterised by intensive spontaneous spreading into surrounding semi-natural grasslands, while non-escaping populations showed no sign of spreading, despite suitable habitats for spontaneous spreading being available.

Seeds from three distant populations were also collected - one from the primary distribution area of $L$. coronaria (LC7; Istanbul, Turkey), one from the secondary distribution area of S. byzantina (SB9; Dublin, 
Ireland), and one from the primary distribution area of S. byzantina (SB10; Tehran, Iran) for basic cytological testing of genome size (see Online Resource table).

Before setting up the experiments, the seeds were dark-stratified at $-16^{\circ} \mathrm{C}$ for six weeks to break dormancy, then surface-disinfected in 70\% (v/v) ethanol for $1 \mathrm{~min}$ and immersed in 50\% (v/v) bleach solution ( $<5 \%$ sodium hypochlorite; Ślesak et al. 2017).

Three germination traits were measured: i) final germination, calculated as total number of germinated seeds at the end of the germination period, ii) differences in germination over time, calculated as the number of germinated seeds in each time interval, and iii) germination delay (hereinafter GD), calculated as the number of days until first germination recorded (Cerabolini et al. 2004; Pepe et al. 2020). Each population sample consisted of 30 seeds in three replicates for each treatment.

Differences in germination rate between escaping and non-escaping populations were tested using seeds grown in the $22 / 15^{\circ} \mathrm{C}$ regime, as this was shown to be optimal for both species during the previous experiment of this study (see above).

\section{Data analysis}

Differences in seed germination between populations and between temperature regimes were tested by comparing the observed 'final germination' counts using general linear models (GLM) with Poisson distribution. Full models were simplified using posterior comparisons and the most plausible models selected based on the Akaike information criterion (Akaike 1978; Crawley 2012), using backward selection. Differences in 'germination over time' were tested using repeated measures ANOVA (RM ANOVA), where the number of germinated seeds at a particular time was used as the response variable Lepš and Šmilauer 2016), while observations taken over the 30 days, temperature and population were used as predictors. The effects of experimental temperatures on seed germination were assessed using a multivariate test based on Wilks' $\Lambda$ statistic value, used for within-subject effects (Mardia et al. 1979).

GLMs were used to assess differences in germination rate between escaping and non-escaping populations of both species, using the number of germinated seeds as the response variable and population characteristic of escaping populations as the predictor (binomial distribution).

All analyses were performed using R software (R Development Core Team 2019), with differences considered significant at $P \leq 0.05$.

\section{Results}

\section{Population genome size variability}

Flow cytometric analysis confirmed genome size homogeneity in all populations of both species in their secondary area of distribution (Fig. 1), with S. byzantina populations ranging from 1.55 to $1.63 \mathrm{pg}$ (2C- 
values), and L. coronaria populations ranging from 6.40 to $6.58 \mathrm{pg}$ (2C-values) (see Online Resource table).

\section{Seed germination \\ Lychnis coronaria}

Temperature had a highly significant impact on final germination in all populations tested $\left(\mathrm{F}_{3,41}=\right.$ $1766.99, P<0.001)$, with posteriori comparisons distinguishing two levels of significance, i.e. up to $10 / 5^{\circ} \mathrm{C}\left(\overline{\mathrm{x}} \pm \mathrm{SE} ; 0.88 \pm 1.83\right.$; SE: Standard Error of Mean) and $>15 / 10^{\circ} \mathrm{C}(29.54 \pm 0.91)$ (average per Petri dish; Fig. 2). While germination at temperatures $<10 / 5^{\circ} \mathrm{C}$ was low, with final germination at $2.9 \%$ (21 of 720 seeds germinating), final germination at temperatures $>15 / 10^{\circ} \mathrm{C}$ was exceedingly high at $98.5 \%(709$ of 720 seeds germinating).

While GD was significantly affected by temperature $\left(F_{3,41}=93.53, P<0.001\right)$, population had no significant effect $\left(F_{3,41}=0.41, P=0.75\right)$. Seeds germinated later at lower temperatures, with a $G D$ of three days at $22 / 15^{\circ} \mathrm{C}$, three days at $15 / 10^{\circ} \mathrm{C}$, nineteen days at $10 / 5^{\circ} \mathrm{C}$ and no germination at $5 / 3^{\circ} \mathrm{C}$. There was a non-significant difference in final germination between populations $\left(F_{3,41}=0.97, P=41.67\right)$, the seed germination rate over the first twelve days differed significantly (RM ANOVA, $F_{126}=9.0, P<0.001$ ), primarily due to population LC2 having a lower germination rate at $22 / 15^{\circ} \mathrm{C}$, though this difference later vanished (Fig. 3).

\section{Stachys byzantina}

As with $L$. coronaria, temperature had a highly significant impact on final germination in all populations tested $\left(F_{2,30}=45.21, P<0.001\right)$. Likewise, germination was low at temperatures $<10 / 5^{\circ} \mathrm{C}$, with a final germination rate of $0.3 \%$ ( 1 of 360 seeds germinating), but increased with increasing temperature, with final germination at $15 / 10^{\circ} \mathrm{C}$ reaching $40.3 \%$ (145 of 360 seeds germinating) and the highest final germination being recorded at $22 / 15^{\circ} \mathrm{C}$ at $55.6 \%$ (200 of 360 seeds germinating) (Fig. 4).

There was also a significant difference in seeds germinating between populations $\left(F_{3,30}=11.11, P<\right.$ 0.001 ), with no seeds (all populations) germinating at $10 / 5^{\circ} \mathrm{C}$ (apart from one seed from the SB3 population) and large differences in final germination among populations at higher temperatures, i.e. min. $6.7 \%$ (SB2) and max. $70.0 \%$ (SB4) at $15 / 10^{\circ} \mathrm{C}$ and $\min .28 .9 \%$ (SB3) and max. $74.4 \%$ (SB4) at $22 / 15^{\circ} \mathrm{C}$. There were significant differences in seed germination between all populations and all temperatures over time (RM ANOVA, $F_{84}=11.8, P<0.001$ ), with the strongest effect observed at higher temperatures, i.e. $12.08 \pm 8.21$ at $15 / 10^{\circ} \mathrm{C}$ and $16.70 \pm 5.93$ at $22 / 15^{\circ} \mathrm{C}$ (average per Petri dish). Populations SB1 and SB4 both displayed a higher germination rate than the other populations, with almost all seeds germinating during the first ten days of the experiment (Fig. 5). GD was significantly affected by temperature $\left(F_{2,30}=63.7002, P<10^{-6}\right)$, though again there was no significant effect of 
population $\left(F_{3,30}=1.67, P=0.2\right)$. In all populations, seeds germinated later at lower temperatures, with a GD of two days at $22 / 15^{\circ} \mathrm{C}$, seven days at $15 / 10^{\circ} \mathrm{C}$ and just one seed germinating at $10 / 5^{\circ} \mathrm{C}$.

Difference in germination rate between escaping and non-escaping populations

There was no significant difference in seed germination rate or average seed germination values between escaping and non-escaping populations of $L$. coronaria $\left(\mathrm{F}_{1,16}=0.29, P=0.6\right)$ or $S$. byzantina $\left(\mathrm{F}_{1,22}=\right.$ $0.003, P=0.95)$ (Fig. 6).

\section{Discussion}

Detailed studies of generative reproduction and population ecology, including studies of genetic and cytological variation, have proved to be promising tools providing important information on the determinants of species invasiveness (Moravcová et al. 2010; Suda et al. 2015; Pyšek et al. 2018). Standardised studies on the germination characteristics of plant taxa (Grime et al. 1981; Grime et al. 1988), for example, help clarify the capacity for spreading and the potential for establishment of new populations (Pyšek and Richardson 2007).

In the present study, we describe cytological variability and germination rate in two newly spreading species, S. byzantina and L. coronaria. The seeds of both species displayed optimal germination at temperatures between $15 / 10^{\circ} \mathrm{C}$ and $22 / 15^{\circ} \mathrm{C}$, with S. byzantina closer to $22 / 15^{\circ} \mathrm{C}$ (Figs. 3 and 5). Hence both species, which have similar spreading potentials but different primary distribution areas, proved highly successful at germinating under temperature conditions typical of Central Europe (Iran, Ireland and Turkey were only sampled for testing cytological homogeneity). Differing environmental conditions are usually the main reason plants fail to survive or spread in their secondary distribution area (Richardson et al. 1994; Mack 1996; Richardson et al. 2000); thus, their ability to germinate successfully in this temperature range allowed them to overcome a major barrier between their primary and secondary distribution areas. Though $L$. coronaria was previously classified as non-invasive in the basic IAS screening study of Moravcová et al. (2010), the species has recently begun spreading, with multiple observations of the species escaping from plantations (Kutlvašr et al. 2019; Vojík et al. 2020). Similarly, S. byzantina was originally classified as casual in the study of Pyšek et al. (2012b), but has recently shown similar spreading behaviour as L. coronaria in the field (see Online Resource figure).

Germination, and timing of germination, depends heavily on a combination of factors, including light, temperature and dormancy (Hoyle et al. 2015), with external temperature and available light in particular regulating the enzymes directly involved in germination (Baskin et Baskin 1998). Consequently, these two key factors formed the basis of our study into the germination capabilities of $S$. byzantina and $L$. coronaria.

For Lychnis coronaria, a species with an extremely high germination rates at $22 / 15^{\circ} \mathrm{C}$ (almost $99 \%$ of seeds germinated; see Fig. 3), rapid germination within the first six days of the experiment, and a germination rate that does not differ between populations, our results were similar to those of Moravcová 
et al. (2010). However, we disagree with their suggestion that this species does not display invasive behaviour. The species' high germination rate under conditions typical of its secondary distribution area and its rapid growth both increase its ability to invade new environments (Beerling and Perrins 1993; Gioria et al. 2016), and numerous recent recordings of localised spreading in the field (Vojík et al., in prep.) clearly indicate the high invasive potential of the species. An early and/or rapid germination strategy (Ross and Harper 1972; Gioria and Pyšek 2017) is especially typical for ornamental plants originating from arid or semi-arid environments. Indeed, the same strategy is found in a number of fastgrowing invasive annuals, including Himalayan balsam Impatiens glandulifera, and some of the most invasive monocarpic perennials, including giant hogweed Heracleum mantegazzianum and Chilean rhubarb Gunnera tinctoria (Gioria and Osborne 2009; Gioria and Osborne 2013). The potential for $L$. coronaria to spread invasively is also supported by its high seed production, with a two-year-old plant releasing 19000 seeds on average (counted on plants growing in experimental garden bed). Clearly, therefore, $L$. coronaria must be considered as a new and potentially dangerous invasive species in this country.

Stachys byzantina, given the species' primary distribution area and its thermophilicity, was expected to show highest germination at around $22 / 15^{\circ} \mathrm{C}$, similar to other species of the Lamiaceae family with a similar primary distribution, e.g. basil Ocimum basilicum, which has a germination optimum of $20-30^{\circ} \mathrm{C}$ (Nassar et al. 2013; Elhaj 2015) or Egyptian sage Salvia aegyptiaca, which germinates optimally at $30^{\circ} \mathrm{C}$ (Gorai et al. 2011). Our results confirmed this expectation, with highest germination (55.6\%) indeed occurring at $22 / 15^{\circ} \mathrm{C}$, while almost no seeds germinated $(0.3 \%)$ at temperatures $<10 / 5^{\circ} \mathrm{C}$. Furthermore, two populations examined (SB 1, SB 4) clearly differed from each other - their germination rate at $22 / 15^{\circ} \mathrm{C}$ was $72.8 \%$ and at $15 / 10^{\circ} \mathrm{C}$ was $65.6 \%$ (Fig. 5), which is about $30 \%$ higher than the germination rate of the rest of populations. Both these localities were placed in urban sites, and urban environments and phenomena (e.g. urban heat and dry islands) are known to strongly influence species adaptation (Williams et al. 2015; McDonnell and Hahs 2015), with species changing their ecology and reproductive traits to become more invasive (Dubois and Cheptou 2017). Such phenomenon has been described in several highly invasive European species, including highly invasive common ragweed Ambrosia artemisiifolia (Gorton et al. 2018).

While the results of our experiment confirmed the expected characteristics of such thermophilic species (Baskin and Baskin 1988; Escudero et al. 1997), the final germination rate was relatively high and contradicts the expected reproduction limits typical for rare, often endemic, species (Pavlik et al. 1993; Kaye 1999), though these can vary between specific sites (e.g. with altitude) or with the age of the populations sampled (Giménez-Benavides et al. 2005). Until recently, it was believed that a small primary distribution area would not include many safe sites for sexual propagules (germination conditions), and that this would limit species from spreading in other part of the world (Massey and Whitson 1980). However, there are now numerous examples of rapid and heavy invasion by such species, e.g. I. glandulifera (Beerling and Perrins 1993), suggesting that a species' individual ecological characteristics and its ability to evolve may be all that's needed to produce invasive behaviour (Dlugosch and Parker 2008a). 
We analysed also the cytological variability of both $S$. byzantina and $L$. coronaria to determine differences in ploidy levels among populations. We did not assess genetic diversity as it was expected to be high in both species due to their predominant generative reproduction mode (Crawley 1996).

Nevertheless, genome size variability is a fast screening method for detecting changes in ploidy level or ongoing evolution that can affect seed germination and/or growth rate (Pegtel 1999; Schween et al. 2005; Münzbergová 2006). Polyploidy, for example, can cause differently sized seeds, changes in viability and changes in a species' ability to germinate under stressful conditions (Stevens et al. 2020). Such changes to genome size can significantly influence the ability of an alien species to spread and potentially become invasive (Suda et al. 2015; Pyšek et al. 2018). Our results indicated that both species were cytologically homogenous with no evidence of polyploidy, with all populations of either species having a similar species-specific genome size ( $S$. byzantina 1.55-1.63 pg; L. coronaria 6.40-6.58 pg), levels similar to those given by Zonneveld (2019). Furthermore, reference samples taken from the species' primary area of distribution around Istanbul in Turkey (LC 7) and Tehran in Iran (SB10) showed the same ploidy levels as those from the secondary area (Online Resource table).

\section{Comparison of escaping and non-escaping populations}

Based on field observations (visual detection of escapes), we expected to see a difference in cytological variability and germination rate between escaping and non-escaping populations. Surprisingly, our results failed to show any significant difference in variability and germination rate for either species examined (see Fig. 6), suggesting that germination and genome size are not key factors for escape from plantings. However, spreading into surrounding habitats could be caused by changes in local site conditions, such as management or disturbance regime (Buckley et al. 2007). Both species have now been recorded escaping from urban habitats, especially parks and gardens (Hejný 1997; Barošová and Baroš 2009; Pergl et al. 2016; Kutlvašr et al. 2019; Vojík et al. 2020). While both species are currently classified as naturalised (L. coronaria) or casual (S. byzantina) (Pyšek et al. 2012b), they are likely to become problematic species as they spread into natural or semi-natural habitats, with rural semi-dry grasslands and semi-natural species-rich grasslands and steppes particularly at risk. L. coronaria is a particularly competitive species due to its ability to produce a huge number of viable seeds that can be spread in different ways (e.g. hydrochory, epizoochory), allowing it to spread into faraway habitats (Moravcová et al. 2010). S. byzantina can be spread successfully by either seed or vegetative dispersal. It is also likely that $S$. byzantina could erode the genome of an endangered native species, $S$. germanica, through hybridisation (see Introduction), process generally considered one of the most serious impacts of invasive species on native biota (Largiadèr 2008; Muhlfeld et al. 2014).

Overall, our results suggest that generative spreading of both $L$. coronaria and S. byzantina is directly influenced by environmental factors, such as mean and spring temperature, both of which are likely to increase due to global climate change (Hansen et al. 2006; Anderson et al. 2008). In addition, indirect phenomena such as dry and warm islands in urban habitats (Roth et al. 1989; Lokoshchenko 2017; Yang et al. 2017; Hao et al. 2018) may be increasing the likelihood that these species escape and spread 
further. As such, both species may now pose a real threat to native species, particularly those in Central European mesic and xeric grasslands.

\section{Declarations}

\section{Statements \& Declarations}

\section{Funding}

This study was financially supported by the Internal Grant Agency of the Faculty of Environmental Sciences, Czech University of Life Sciences Prague, Kamýcká 129, Prague - Suchdol, 165 00, Czech Republic (Grant no. 2020B0007). Study was partly supported within the project "DivLand" (SS02030018) from the Technology Agency of the Czech Republic and a long-term research development project (RVO 67985939) from the Czech Academy of Sciences.

\section{Conflict of Interest}

There are no potential conflicts with Ethical Standards and conflicts of interest (financial or nonfinancial). All financial supporting resources are listed.

\section{Author Contribution}

All persons entitled to authorship have been so named, and all authors have seen and agreed to the submitted version of the manuscript. All authors certify that they have no affiliations with or involvement in any organization or entity with any financial interest or non-financial interest in the subject matter or materials discussed in this manuscript.

Availability of data and material

Not applicable.

Animal Research

Not applicable.

Consent to Participate

Not applicable.

Consent to Publish

Not applicable.

Plant Reproducibility

Not applicable. 


\section{Clinical Trials Registration}

Not applicable.

Acknowledgement

This study was financially supported by the Internal Grant Agency of the Faculty of Environmental Sciences, Czech University of Life Sciences Prague, Kamýcká 129, Prague - Suchdol, 165 00, Czech Republic (Grant no. 2020B0007). Study was partly supported within the project "DivLand" (SS02030018) from the Technology Agency of the Czech Republic and a long-term research development project (RVO 67985939) from the Czech Academy of Sciences. We would like to thank the Ecological Department of the Faculty of Environmental Sciences for renting climaboxes, and our colleague Libor Králík for controlling seed germination. Mark Sixsmith, Kevin Roche and Jonáš Gaigr are acknowledged for language correction and Sorour Rahmanian for the collection of seeds from primary distribution.

\section{References}

Akaike H (1978) A Bayesian analysis of the minimum AIC procedure. Springer, New York, NY, pp 275-280

Anderson CB, Likens GE, Rozzi R, Gutiérrez JR, Armesto JJ, Poole A (2008) Integrating science and society through long-term socio-ecological research. Environmental ethics 30:295312. https://doi.org/10.5840/enviroethics200830334

Asnaashari S, Delazar A, Alipour S, Nahar L, Williams A, Pasdaran A, Mojarab M, Azad F, Sarker SD (2010) Chemical composition, free-radical scavenging and insecticidal activities of the aerial parts of Stachys byzantina. Archives of Biological Sciences 62:653-662. https://doi.org/10.2298/ABS1003653A

Barošová I, Baroš A (2009) Zplanění vybraných taxonů trvalek v porostním okraji dřevin. Acta Pruhoniciana 93:89-95. (In Czech).

Baskin CC, Baskin JM (1988) Germination ecophysiology of herbaceous plant species in a temperate region. Am J Bot 75:286-305. https://doi.org/10.1002/j.1537-2197.1988.tb13441.x

Baskin CC, Baskin JM (Jerry M (1998) Seeds: ecology, biogeography, and evolution of dormancy and germination. Academic Press

Beerling DJ, Perrins JM (1993) Impatiens glandulifera Royle (Impatiens Roylei Walp.). The Journal of Ecology 81:367. https://doi.org/10.2307/2261507

Buckley YM, Bolker BM, Rees M (2007) Disturbance, invasion and re-invasion: managing the weedshaped hole in disturbed ecosystems. Ecology Letters 10:809-817. https://doi.org/10.1111/j.14610248.2007.01067.x 
Buhk C, Thielsch A (2015) Hybridisation boosts the invasion of an alien species complex: Insights into future invasiveness. Perspectives in Plant Ecology, Evolution and Systematics 17:274283. https://doi.org/10.1016/j.ppees.2015.05.001

CABI (2019) Lychnis coronaria. In: Invasive species compendium. Wallingford, UK: CAB International. www.cabi.org/isc.

Cerabolini B, De Andreis R, Ceriani RM, Pierce S, Raimondi B (2004) Seed germination and conservation of endangered species from the Italian Alps: Physoplexis comosa and Primula glaucescens. Biological Conservation 117:351-356. https://doi.org/10.1016/j.biocon.2003.12.011

Chytrý M, Danihelka J, Kaplan Z, Wild J, Holubová D, Novotný P, Řezníčková M, Rohn M, Dřevojan P, Grulich V, Klimešová J, Lepš J, Lososová Z, Pergl J, Sádlo J, Šmarda P, Štěpánková P, Tichý L, Axmanová I, Bartušková A, Blažek P, Chrtek Jr J, Fischer FM, Guo W-Y, Herben T, Janovský Z, Konečná M, Kühn I, Moravcová $L$, Petřík P, Pierce $S$, Prach $K$, Prokešová $H$, Štech $M$, Těšitel $J$, Těšitelová $T$, Večeřa $M, Z$ Zelený $D$, Pyšek P (2021) Pladias database of the Czech flora and vegetation. Preslia 93:187. https://doi.org/10.23855/preslia.2021.001

Crawley MJ (2012) The R book, 2nd edn. John Wiley \& Sons, London

Crawley MJ (1996) Plant ecology, 2nd editio. Blackwell Publishing Ltd., Oxford, UK

Culek M, Grulich V, Laštůvka Z a Divíšek J (2013) Biogeografické regiony České republiky. 1. vyd. Masarykova univerzita. Brno. (In Czech).

Cullen J, Knees SG, Cubey HS, Shaw JMH (2011) The European garden flora flowering plants: a manual for the identification of plants cultivated in Europe, both out-of-doors and under glass, 2nd editio.

Cambridge University Press

Dehnen-Schmutz K, Touza J (2008) Plant invasions and ornamental horticulture: Pathway, propagule pressure and the legal framework. In: Floriculture, ornamental and plant biotechnology: advances and topical issues. Global Science Books, pp 15-21

Dimke KC, Still SK, Gardner DS (2008) Effect of overwintering environment on the survival of 30 species of herbaceous perennials. Journal of Environmental Horticulture 26:222226. https://doi.org/10.24266/0738-2898-26.4.222

Dlugosch KM, Parker IM (2008a) Founding events in species invasions: Genetic variation, adaptive evolution, and the role of multiple introductions. Molecular Ecology 17:431449. https://doi.org/10.1111/j.1365-294X.2007.03538.x

Dlugosch KM, Parker IM (2008b) Invading populations of an ornamental shrub show rapid life history evolution despite genetic bottlenecks. Ecology Letters 11:701-709. https://doi.org/10.1111/j.14610248.2008.01181.x

Page $13 / 26$ 
Downey PO, Williams MC, Whiffen LK, Auld BA, Hamilton MA, Burley AL, Turner PJ (2010) Managing alien plants for biodiversity outcomes-the need for triage. Invasive Plant Science and Management 3:111. https://doi.org/10.1614/ipsm-09-042.1

Dubois J, Cheptou PO (2017) Effects of fragmentation on plant adaptation to urban environments. Philosophical Transactions of the Royal Society B: Biological Sciences 372. https://doi.org/10.1098/rstb.2016.0038

Dullinger I, Wessely J, Bossdorf O, Dawson W, EssI F, Gattringer A, Klonner G, Kreft H, Kuttner M, Moser D, Pergl J, Pyšek P, Thuiller W, van Kleunen M, Weigelt P, Winter M, Dullinger S (2017) Climate change will increase the naturalization risk from garden plants in Europe. Global Ecology and Biogeography 26:4353. https://doi.org/10.1111/geb.12512

Elhaj HKD (2015) Effects of temperature and light on seed germination of basil (Ocimum basilicum L.). University of Gezira

Escudero A, Carnes LF, Pérez-García F (1997) Seed germination of gypsophytes and gypsovags in semiarid central Spain. Journal of Arid Environments 36:487-497. https://doi.org/10.1006/jare.1996.0215

Estoup A, Ravigné V, Hufbauer R, Vitalis R, Gautier M, Facon B (2016) Is there a genetic paradox of biological invasion? Annual Review of Ecology, Evolution, and Systematics 47:5172. https://doi.org/10.1146/annurev-ecolsys-121415-032116

Ewel JJ, Putz FE (2004) A place for alien species in ecosystem restoration. Frontiers in Ecology and the Environment 2:354-360. https://doi.org/10.1890/1540-9295

Flory SL, Long F, Clay K (2011) Invasive Microstegium populations consistently outperform native range populations across diverse environments. Ecology 92:2248-2257. https://doi.org/10.1890/11-0363.1

Giménez-Benavides L, Escudero A, Pérez-García F (2005) Seed germination of high mountain Mediterranean species: Altitudinal, interpopulation and interannual variability. Ecological Research 20:433-444. https://doi.org/10.1007/s11284-005-0059-4

Gioria M, Osborne B (2009) Assessing the impact of plant invasions on soil seed bank communities: use of univariate and multivariate statistical approaches. Journal of Vegetation Science 20:547556. https://doi.org/10.1111/j.1654-1103.2009.01054.x

Gioria M, Osborne BA (2013) Biological flora of the British Isles: Gunnera tinctoria. Journal of Ecology 101:243-264. https://doi.org/10.1111/1365-2745.12022

Gioria M, Pyšek P (2017) Early bird catches the worm: germination as a critical step in plant invasion. Biological Invasions 19:1055-1080. https://doi.org/10.1007/s10530-016-1349-1 
Gioria M, Pyšek P, Osborne BA (2016) Timing is everything: does early and late germination favor invasions by herbaceous alien plants? https://doi.org/10.1093/jpe/rtw105

Glawe DA, Koike ST (2018) First report of powdery mildew of Stachys byzantina (lamb's ear) caused by Neoerysiphe galeopsidis in North America. Plant Health Progress 8, https://doi.org/10.1094/PHP-20071217-01-BR

Gorai M, Gasmi H, Neffati M (2011) Factors influencing seed germination of medicinal plant Salvia aegyptiaca L. (Lamiaceae). Saudi Journal of Biological Sciences 18:255260. https://doi.org/10.1016/J.SJBS.2011.01.004

Gorton AJ, Moeller DA, Tiffin P (2018) Little plant, big city: A test of adaptation to urban environments in common ragweed (Ambrosia artemisiifolia). In: Proceedings of the Royal Society B: Biological Sciences. Royal Society Publishing, pp 1-10. https://doi.org/10.1098/rspb.2018.0968

Grime JP, Hodgson J, Hunt R (1988) Comparative plant ecology: a functional approach to common British species. Springer Netherlands

Grime JP, Mason G, Curtis A V., Rodman J, Band SR (1981) A comparative study of germination characteristics in a local flora. The Journal of Ecology 69:1017. https://doi.org/10.2307/2259651

Grulich V (2017) The Red list of vascular plants of the Czech Republic. Príroda 75-132.

Haeuser E, Block S, Dawson W, Thuiller W, Dullinger S, Bossdorf O, Carboni M, Conti L, Moser D, Winter M, Klonner G, Weigelt P, Münkemüller T, Parepa M, Talluto M V (2018) European ornamental garden flora as an invasion debt under climate change. Journal of Applied Ecology 55:23862395. https://doi.org/10.1111/1365-2664.13197

Hansen J, Sato M, Ruedy R, Lo K, Lea DW, Medina-Elizade M (2006) Global temperature change. PNAS 103:6. https://doi.org/10.1073/pnas.0606291103

Hao L, Huang X, Qin M, Liu Y, Li W, Sun G (2018) Ecohydrological processes explain urban dry island effects in a wet region, southern China. Water Resources Research 54:67576771. https://doi.org/10.1029/2018WR023002

Hassan M, Harmelin-Vivien M, Bonhomme F (2003) Lessepsian invasion without bottleneck: Example of two rabbitfish species (Siganus rivulatus and Siganus luridus). Journal of Experimental Marine Biology and Ecology 291:219-232. https://doi.org/10.1016/S0022-0981

Hejný Slavomil (1997) Květena České republiky. Academia, Praha (In Czech)

Jarić I, Courchamp F, Correia RA, Crowley SL, Essl F, Fischer A, González-Moreno P, Kalinkat G, Lambin X, Lenzner B, Meinard Y, Mill A, Musseau C, Novoa A, Pergl J, Pyšek P, Pyšková K, Robertson P, Schmalensee M, Shackleton RT, Stefansson RA, Štajerová K, Veríssimo D, Jeschke JM (2020) The role of species 
charisma in biological invasions. Frontiers in Ecology and the Environment 18:345353. https://doi.org/10.1002/fee.2195

Jeelani SM, Rani S, Kumar S, Kumari S, Gupta RC (2011) Meiotic studies in some members of Caryophyllaceae juss. from the western Himalayas. Acta Biologica Cracoviensia Series Botanica 53:8695. https://doi.org/10.2478/v10182-011-0012-5

Jiang L, Dunn BL, Wang Y, Goad CL (2016) Responses to propagation substrate and rooting hormone products to facilitate asexual propagation of Silene chalcedonica and Silene coronaria. Journal of Environmental Horticulture 34:80-83. https://doi.org/10.24266/0738-2898-34.3.80

Kaye TN (1999) From flowering to dispersal: Reproductive ecology of an endemic plant, Astragalus australis var. olympicus (Fabaceae). American Journal of Botany 86:12481256. https://doi.org/10.2307/2656772

Kendle T, Stoneham J (2014) Horticulture and society. In: Horticulture: Plants for people and places. Springer Netherlands, pp 953-964

Klonner G, Dullinger I, Wessely J, Bossdorf O, Carboni M, Dawson W, EssI F, Gattringer A, Haeuser E, van Kleunen M, Kreft H, Moser D, Pergl J, Pyšek P, Thuiller W, Weigelt P, Winter M, Dullinger S (2017) Will climate change increase hybridization risk between potential plant invaders and their congeners in Europe? Diversity and Distributions 23:934-943. https://doi.org/10.1111/ddi.12578

Köppler MR, Kowarik I, Kühn N, Von der Lippe M (2014) Enhancing wasteland vegetation by adding ornamentals: Opportunities and constraints for establishing steppe and prairie species on urban demolition sites. Landscape and Urban Planning 126:1-

9. https://doi.org/10.1016/j.landurbplan.2014.03.001

Kutlvašr J, Baroš A, Pyšek P, Pergl J (2020) Changes in assemblages of native and alien plants in perennial plantations: prairie species stabilize the community composition. NeoBiota 63:3956. https://doi.org/10.3897/neobiota.63.51109

Kutlvašr J, Pergl J, Baroš A, Pyšek P (2019) Survival, dynamics of spread and invasive potential of species in perennial plantations. Biological Invasions 1-13. https://doi.org/10.1007/s10530-018-1847-4

Largiadèr CR (2008) Hybridization and introgression between native and alien species. Biological Invasions 275-292. https://doi.org/10.1007/978-3-540-36920-2_16

Lepš J, Šmilauer P (2016) Biostatistika, 1st edn. Nakladatelství Jihočeské univerzity v Českých Budějovicích, České Budějovice (In Czech)

Lindqvist C, Albert VA (2017) Origin of the Hawaiian endemic mints within North American Stachys (Lamiaceae). American Journal of Botany 89:1709-1724. https://doi.org/10.3732/ajb.89.10.1709 
Lokoshchenko MA (2017) Urban heat island and urban dry island in Moscow and their centennial changes. Journal of Applied Meteorology and Climatology 10:2729-

2745. https://doi.org/10.1175/JAMC-D-16-0383.1

Lososová Z, de Bello F, Chytrý M, Kühn I, Pyšek P, Sádlo J, Winter M, Zelený D (2015) Alien plants invade more phylogenetically clustered community types and cause even stronger clustering. Global Ecology and Biogeography 24:786-794. https://doi.org/10.1111/geb.12317

Mack RN (1996) Biotic barriers to plant naturalization. In: Proceedings of the 9th international symposium on biological control of weeds, Stellenbosch, South Africa, 19-26 January 1996. University of Cape Town, Stellenbosch, pp 39-46

Mardia KV, Kent JT, Bibby JM (1979) Multivariate analysis. Academic Press, Leeds

Massey J, Whitson P (1980) Species biology, the key to plant preservation. Rhodora 82:97-103

McDonnell MJ, Hahs AK (2015) Adaptation and adaptedness of organisms to urban environments. Annual Review of Ecology, Evolution, and Systematics 46:261-280. https://doi.org/10.1146/annurevecolsys-112414-054258

McNeely JA (2001) An introduction to human dimensions of invasive alien species. In: Mcneely JA (ed) The great reshuffling human dimensions of invasive alien species. IUCN, Gland, Switzerland and Cambridge, UK, pp 5-20

Merkel A (2019) Climate-Data.org. https://en.climate-data.org.

Meyerson LA, Pyšek P, Lučanová M, Wigginton S, Tran C-T, Cronin JT (2020) Plant genome size influences stress tolerance of invasive and native plants via plasticity. Ecosphere 11:120. https://doi.org/10.1002/ECS2.3145

Moravcová L, Pyšek P, Jarošík V, Havličcková V, Zákravský P (2010) Reproductive characteristics of neophytes in the Czech Republic: Traits of invasive and non-invasive species. Preslia 82:365390. https://doi.org/none

Morri C, Montefalcone M, Gatti G, Vassallo P, Paoli C, Bianchi CN (2019) An alien invader is the cause of homogenization in the recipient ecosystem: a simulation-like approach. Diversity 11. https://doi.org/10.3390/d11090146

Muhlfeld CC, Kovach RP, Jones LA, Al-Chokhachy R, Boyer MC, Leary RF, Lowe WH, Luikart G, Allendorf FW (2014) Invasive hybridization in a threatened species is accelerated by climate change. Nature Climate Change 2014 4:7 4:620-624. https://doi.org/10.1038/nclimate2252

Münzbergová Z (2006) Ploidy level interacts with population size and habitat conditions to determine the degree of herbivory damage in plant populations. Nord Soc Oikos 115:443- 
452. https://doi.org/10.1111/j.2006.0030-1299.15286.x

Nassar MA, Mohamed SN, El-Segai MU (2013) Botanical studies on Ocimum basilicum L. (Lamiaceae). Research Journal of Agriculture and Biological Sciences 9:150-163

Otto F (1990) DAPI staining of fixed cells for high-resolution flow cytometry of nuclear DNA. Methods in cell biology 33:105-10

Pavlik BM, Ferguson N, Nelson M (1993) Assessing limitations on the growth of endangered plant populations, II. Seed production and seed bank dynamics of Erysimum capitatum ssp. Angustatum and Oenothera deltoides ssp. Howellii. Biological Conservation 65:267-278. https://doi.org/10.1016/00063207(93)90059-A

Pegtel DM (1999) Effect of ploidy level on fruit morphology, seed germination and juvenile growth in scurvy grass (Cochlearia officinalis L. s.l., Brassicaceae). Plant Species Biology 14:201215. https://doi.org/10.1046/j.1442-1984.1999.00019.x

Pepe M, Gratani L, Fabrini G, Varone L (2020) Seed germination traits of Ailanthus altissima, Phytolacca americana and Robinia pseudoacacia in response to different thermal and light requirements. Plant Species Biology 35:300-314. https://doi.org/10.1111/1442-1984.12286

Pergl J, Sádlo J, Petřík P, Danihelka J, Chrtek J, Hejda M, Moravcová L, Perglová I, Štajerová K, Pyšek P (2016) Dark side of the fence: ornamental plants as a source of wild-growing flora in the Czech Republic. Preslia 88:163-184

POWO (2019). Plants of the world online. Facilitated by the Royal Botanic Gardens, Kew. Published on the Internet; http://www.plantsoftheworldonline.org/ Retrieved 13.05.2021

Price EPF, Spyreas G, Matthews JW (2018) Biotic homogenization of regional wetland plant communities within short time-scales in the presence of an aggressive invader. Journal of Ecology 106:11801190. https://doi.org/10.1111/1365-2745.12883

Puillandre N, Dupas S, Dangles O, Zeddam JL, Capdevielle-Dulac C, Barbin K, Torres-Leguizamon M, Silvain JF (2008) Genetic bottleneck in invasive species: The potato tuber moth adds to the list. Biological Invasions 10:319-333. https://doi.org/10.1007/s10530-007-9132-y

Pyšek P (2007) Master of all traits: can we successfully fight giant hogweed. In: Pyšek P, Cock $M$, Nentwig W, Ravn $\mathrm{H}$ (eds) Ecology and management of giant hogweed (Heracleum mantegazzianum). CABI Publishing, pp 297-312

Pyšek P, Chytrý M, Pergl J, Sádlo J, Wild J (2012a) Plant invasions in the Czech Republic: Current state, introduction dynamics, invasive species and invaded habitats. Preslia 84:575-629 
Pyšek P, Danihelka J, Sádlo J, Chrtek J, Chytrý M, Jarošík V, Kaplan Z, Krahulec F, Moravcová L, Pergl J, Štajerová K, Tichý L (2012b) Catalogue of alien plants of the Czech Republic (2nd edition): Checklist update, taxonomic diversity and invasion patterns. Preslia 84:155-255

Pyšek P, Hulme PE, Simberloff D, Bacher S, Blackburn TM, Carlton JT, Dawson W, Essl F, Foxcroft LC, Genovesi P, Jeschke JM, Kühn I, Liebhold AM, Mandrak NE, Meyerson LA, Pauchard A, Pergl J, Roy HE, Seebens H, Kleunen M van, Vilà M, Wingfield MJ, Richardson DM (2020) Scientists warning on invasive alien species. Biological Reviews 95:1511-1534. https://doi.org/10.1111/BRV.12627

Pyšek P, Jarošík V, Pergl J, Randall R, Chytrý M, Kühn I, Tichý L, Danihelka J, Chrtek Jun J, Sádlo J (2009) The global invasion success of Central European plants is related to distribution characteristics in their native range and species traits. Diversity and Distributions 15:891-903. https://doi.org/10.1111/j.14724642.2009.00602.x

Pyšek P, Richardson DM (2007) Traits associated with invasiveness in alien plants: where do we stand? In: Biological Invasions. Springer Berlin Heidelberg, pp 97-125

Pyšek P, Skálová H, Čuda J, Guo W-Y, Doležal J, Kauzál O, Lambertini C, Pyšková K, Brix H, Meyerson LA, W-y G (2019) Physiology of a plant invasion: biomass production, growth and tissue chemistry of invasive and native Phragmites australis populations. Preslia 91:5175. https://doi.org/10.23855/preslia.2019.051

Pyšek P, Skálová H, Čuda J, Guo W-Y, Suda J, Doležal J, Kauzál O, Lambertini C, Lučanová M, Mandáková T, Moravcová L, Pyšková K, Brix H, Meyerson LA (2018) Small genome separates native and invasive populations in an ecologically important cosmopolitan grass. Ecology 99:7990. https://doi.org/10.1002/ecy.2068

R Development Core Team (2019) R: A language and environment for statistical computing.

Rejmánek M (1996) A theory of seed plant invasiveness: The first sketch. Biological Conservation 78:171-181. https://doi.org/10.1016/0006-3207(96)00026-2

Relf D, Dorn S (1995) Horticulture: Meeting the needs of special populations. HortTechnology 5:94103. https://doi.org/10.21273/horttech.5.2.94

Richardson DM, Pyšek P, Rejmánek M, Barbour MG, Panetta FD, West CJ (2000) Naturalization and invasion of alien plants: concepts and definitions. Diversity and Distributions 6:93107. https://doi.org/10.1046/j.1472-4642.2000.00083.x

Richardson DM, Williams PA, Hobbs RJ (1994) Pine invasions in the Southern Hemisphere: determinants of spread and invadability. Journal of Biogeography 21:511-527

Ross MA, Harper JL (1972) Occupation of biological space during seedling establishment. The Journal of Ecology 60:77. https://doi.org/10.2307/2258041

Page 19/26 
Roth M, Oke TR, Emery WJ (1989) Satellite-derived urban heat islands from three coastal cities and the utilization of such data in urban climatology. International Journal of Remote Sensing 10:16991720. https://doi.org/10.1080/01431168908904002

Saad L, Tiébré MS, Hardy OJ, Mahy G, Vanderhoeven S (2011) Patterns of hybridization and hybrid survival in the invasive alien Fallopia complex (Polygonaceae). Plant Ecology and Evolution 144. https://doi.org/10.5091/plecevo.2011.444

Schönswetter P, Suda J, Popp M, Weiss-Schneeweiss H, Brochmann C (2007) Circumpolar phylogeography of Juncus biglumis (Juncaceae) inferred from AFLP fingerprints, cpDNA sequences, nuclear DNA content and chromosome numbers. Molecular Phylogenetics and Evolution 42:92103. https://doi.org/10.1016/j.ympev.2006.06.016

Schween G, Schulte J, Reski R, Hohe A (2005) Effect of ploidy level on growth, differentiation, and morphology in Physcomitrella patens. The Bryologist 108:27-35. https://doi.org/10.1639/00072745(2005)108[27:EOPLOG]2.0.C0;2

Shackleton RT, Richardson DM, Shackleton CM, Bennett B, Crowley SL, Dehnen-Schmutz K, Estévez RA, Fischer A, Kueffer C, Kull CA, Marchante E, Novoa A, Potgieter LJ, Vaas J, Vaz AS, Larson BMH (2019) Explaining people's perceptions of invasive alien species: A conceptual framework. Journal of Environmental Management 229:10-26. https://doi.org/10.1016/j.jenvman.2018.04.045

Ślesak H, Dziedzic K, Dagmara Kwolek ; Cygan M, Patryk Mizia ; Olejniczak P, Joachimiak AJ (2017) Female versus male: Rumex thyrsiflorus Fingerh. under in vitro conditions. Does sex influence in vitro morphogenesis? Plant Cell, Tissue and Organ Culture (PCTOC) 129:521532. https://doi.org/10.1007/s11240-017-1197-4

Stevens A V., Nicotra AB, Godfree RC, Guja LK (2020) Polyploidy affects the seed, dormancy and seedling characteristics of a perennial grass, conferring an advantage in stressful climates. Plant Biology 22:500513. https://doi.org/10.1111/plb.13094

Suda J, Meyerson LA, Leitch IJ, Pyšek P (2015) The hidden side of plant invasions: the role of genome size. New Phytologist 994-1007. https://doi.org/10.1111/nph.13107

van Kleunen M, Essl F, Pergl J, Brundu G, Carboni M, Dullinger S, Early R, González-Moreno P, Groom QJ, Hulme PE, Kueffer C, Kühn I, Máguas C, Maurel N, Novoa A, Parepa M, Pyšek P, Seebens H, Tanner R, Touza J, Verbrugge L, Weber E, Dawson W, Kreft H, Weigelt P, Winter M, Klonner G, Talluto M V., DehnenSchmutz K (2018) The changing role of ornamental horticulture in alien plant invasions. Biological Reviews 93:1421-1437. https://doi.org/10.1111/brv.12402

van Kleunen M, Johnson SD, Fischer M (2007) Predicting naturalization of southern African Iridaceae in other regions. Journal of Applied Ecology 44:594-603. https://doi.org/10.1111/j.1365-

2664.2007.01304.x

Page 20/26 
Vilà M, Espinar JL, Hejda M, Hulme PE, Jarošík V, Maron JL, Pergl J, Schaffner U, Sun Y, Pyšek P (2011) Ecological impacts of invasive alien plants: A meta-analysis of their effects on species, communities and ecosystems. Ecology Letters 14:702-708. https://doi.org/10.1111/J.1461-0248.2011.01628.X

Vojík M, Sádlo J, Petřík P, Pyšek P, Man M, Pergl J (2020) Two faces of parks: sources of invasion and habitats for threatened native plants. Preslia 92:353-373. https://doi.org/10.23855/preslia.2020.353

Wade GL, Mengak MT (2010) Deer-tolerant ornamental plants. UGA Warnell School of Forestry and Natural Resources

Wan J, Oduor AMO, Pouteau R, Wang B, Chen L, Yang B, Yu F, Li J (2020) Can polyploidy confer invasive plants with a wider climatic tolerance? A test using Solidago canadensis. Ecology and Evolution 10:5617-5630. https://doi.org/10.1002/ECE3.6303

Williams NSG, Hahs AK, Vesk PA (2015) Urbanisation, plant traits and the composition of urban floras. Perspectives in Plant Ecology, Evolution and Systematics 17:7886. https://doi.org/10.1016/j.ppees.2014.10.002

Williams NSG, Rayner JP, Raynor KJ (2010) Green roofs for a wide brown land: Opportunities and barriers for rooftop greening in Australia. Urban Forestry and Urban Greening 9:245251. https://doi.org/10.1016/j.ufug.2010.01.005

Yang A-S, Juan Y-H, Wen C-Y, Chang C-J (2017) Numerical simulation of cooling effect of vegetation enhancement in a subtropical urban park. Applied Energy 192:178200. https://doi.org/10.1016/j.apenergy.2017.01.079

Zhou WZ (1995) The role of horticulture in human history and culture. Acta Horticulturae 4152. https://doi.org/10.17660/actahortic.1995.391.3

Zonneveld BJM (2019) The DNA weights per nucleus (genome size) of more than 2350 species of the flora of the Netherlands, of which 1370 are new to science, including the pattern of their DNA peaks. Forum geobotanicum 8:24-78. https://doi.org/10.3264/FG.2019.1022

\section{Figures}




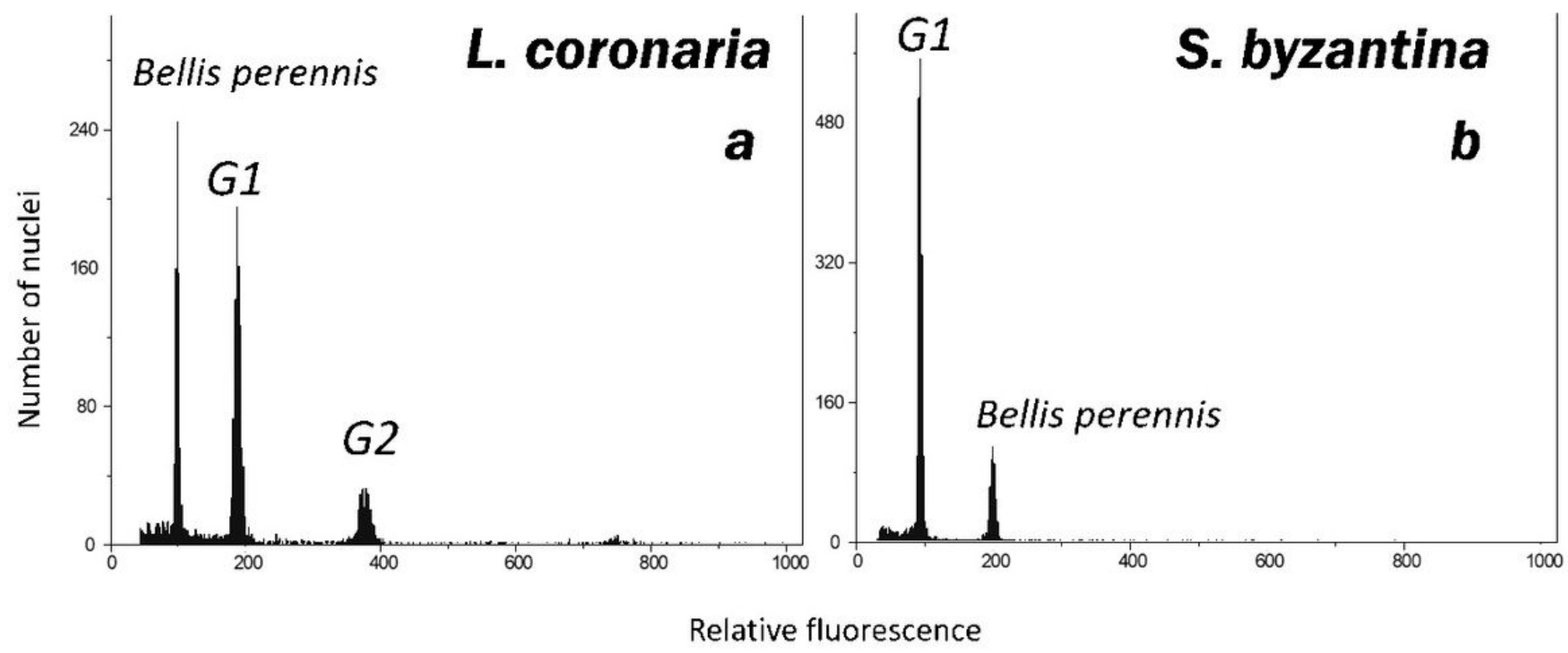

Figure 1

Flow cytometric histograms (nuclei stained with propidium iodide) for Lychnis coronaria and Stachys byzantina, with Bellis perennis used as an internal reference standard for both species (placed at 100 relative fluorescence for $L$. coronaria (a) and at 200 relative fluorescence for $S$. byzantina (b)). The G1 peak represents nuclei with DNA 2C, while the G2 peak represents nuclei with DNA 4C (G2 phases of the cell cycle with double the amount of DNA present) 


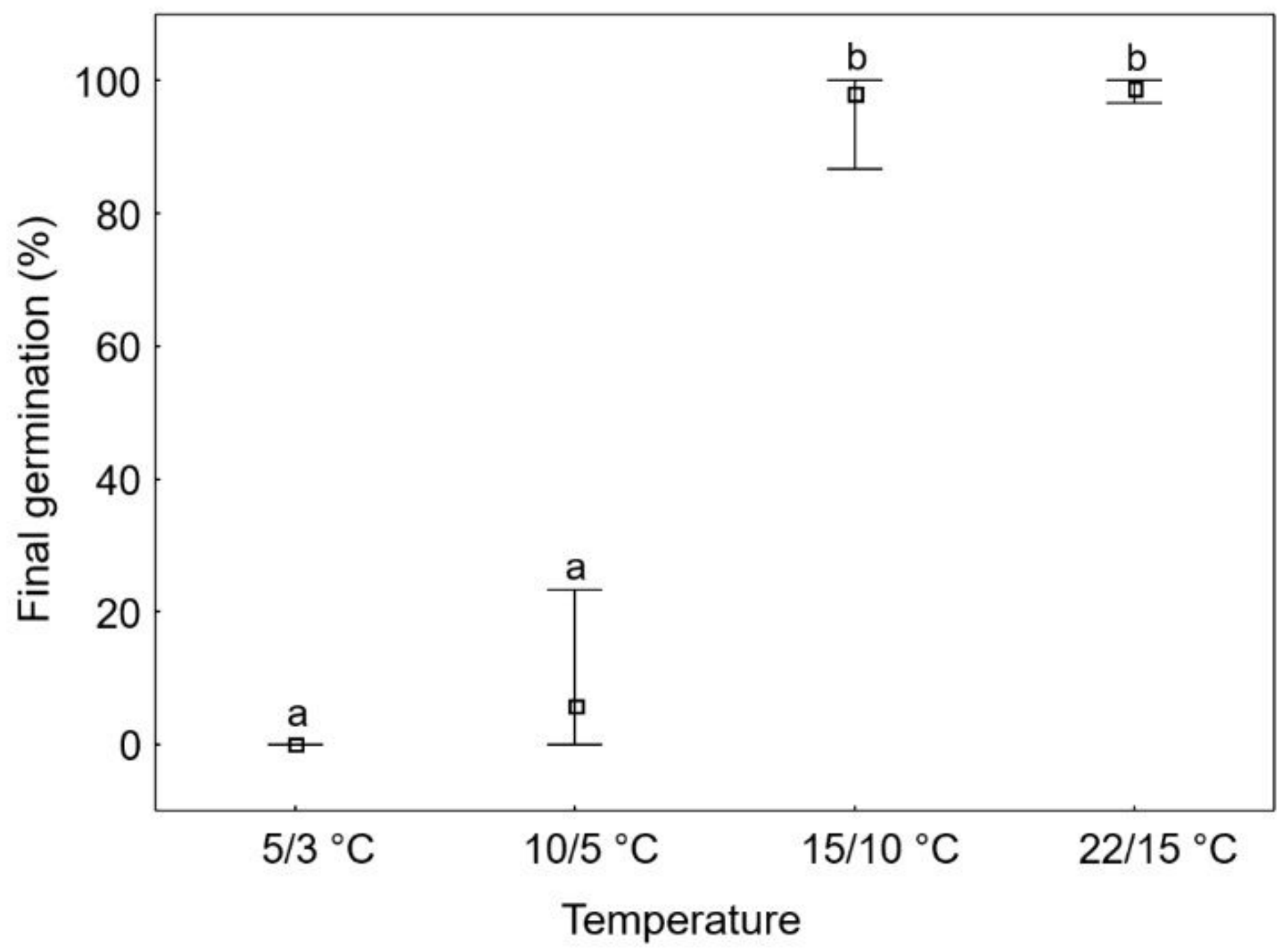

Figure 2

Influence of temperature on final germination of Lychnis coronaria, showing two contrasting responses between treatment levels $5 / 3{ }^{\circ} \mathrm{C}$ and $10 / 5^{\circ} \mathrm{C}$ vs. $15 / 10{ }^{\circ} \mathrm{C}$ and $22 / 15^{\circ} \mathrm{C}$. Squares $=$ means of final germinated seeds, whiskers $=$ min-max; different letters at the end of each treatment row indicate a statistically significant difference $(P<0.05)$ 
$10 / 5^{\circ} \mathrm{C}$

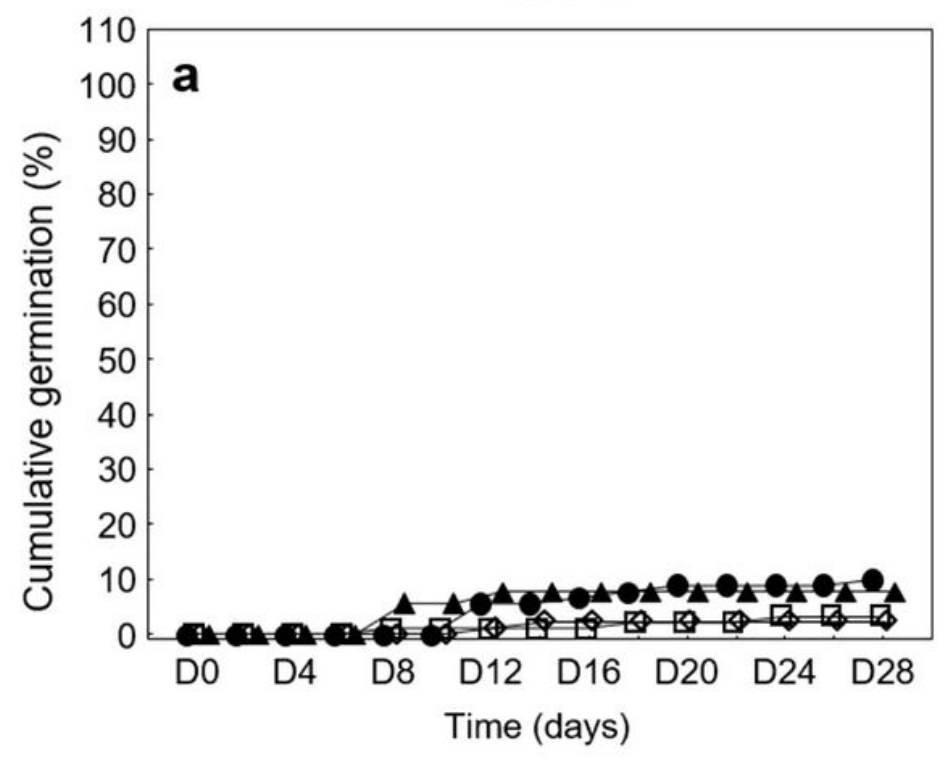

$22 / 15^{\circ} \mathrm{C}$

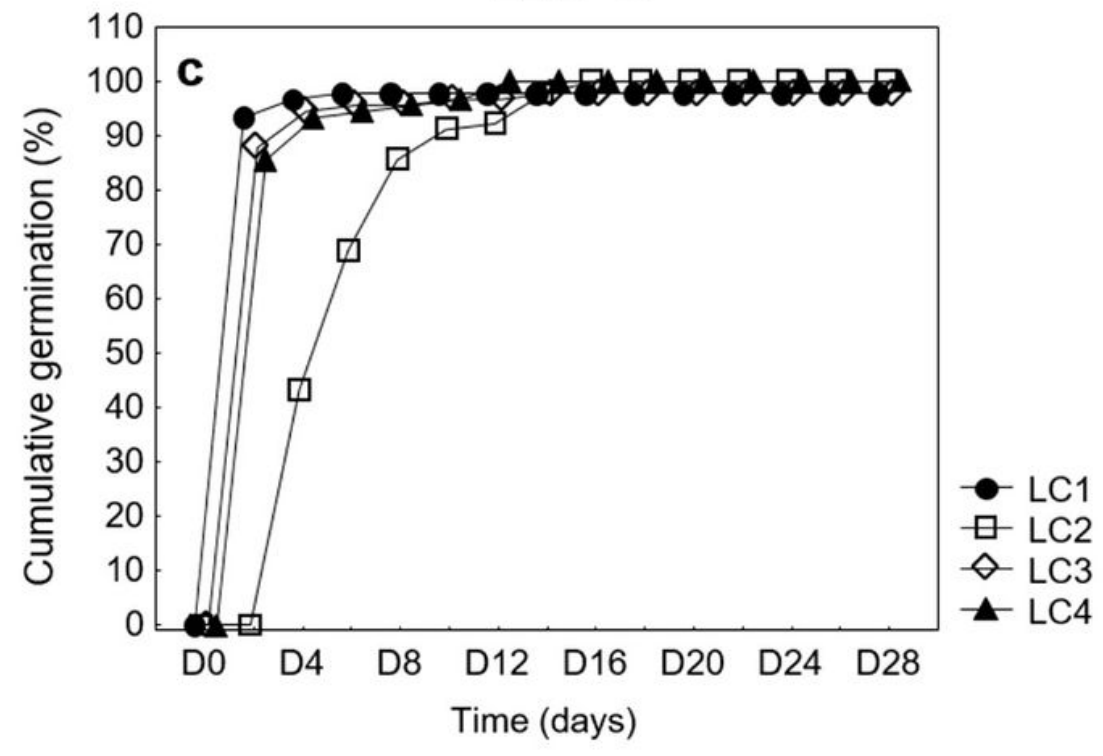

$15 / 10^{\circ} \mathrm{C}$

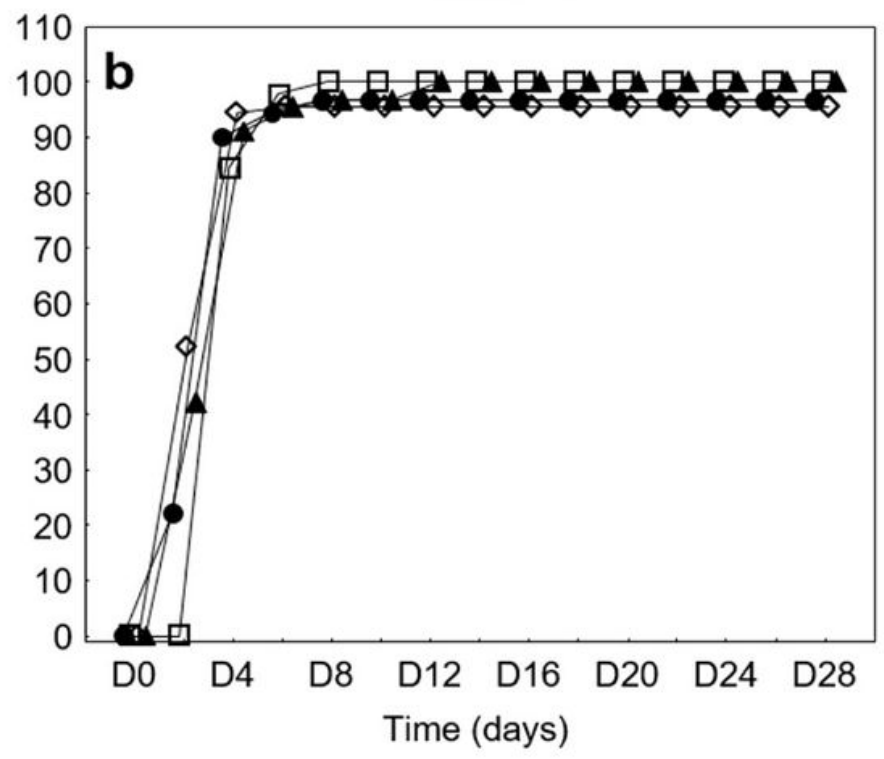

Figure 3

Time course for Lychnis coronaria seed germination under different temperature regimes $\left(\mathrm{a}: 10 / 5^{\circ} \mathrm{C}\right.$; b: $15 / 10^{\circ} \mathrm{C}$; $\mathrm{C}: 22 / 15^{\circ} \mathrm{C}$ ). The results for the $5 / 3{ }^{\circ} \mathrm{C}$ temperature regime are not shown as no seeds germinated, giving a final germination of $0 \%$ ). LC1-LC4 represent particular localities of sampled populations (see Online Resource table) 


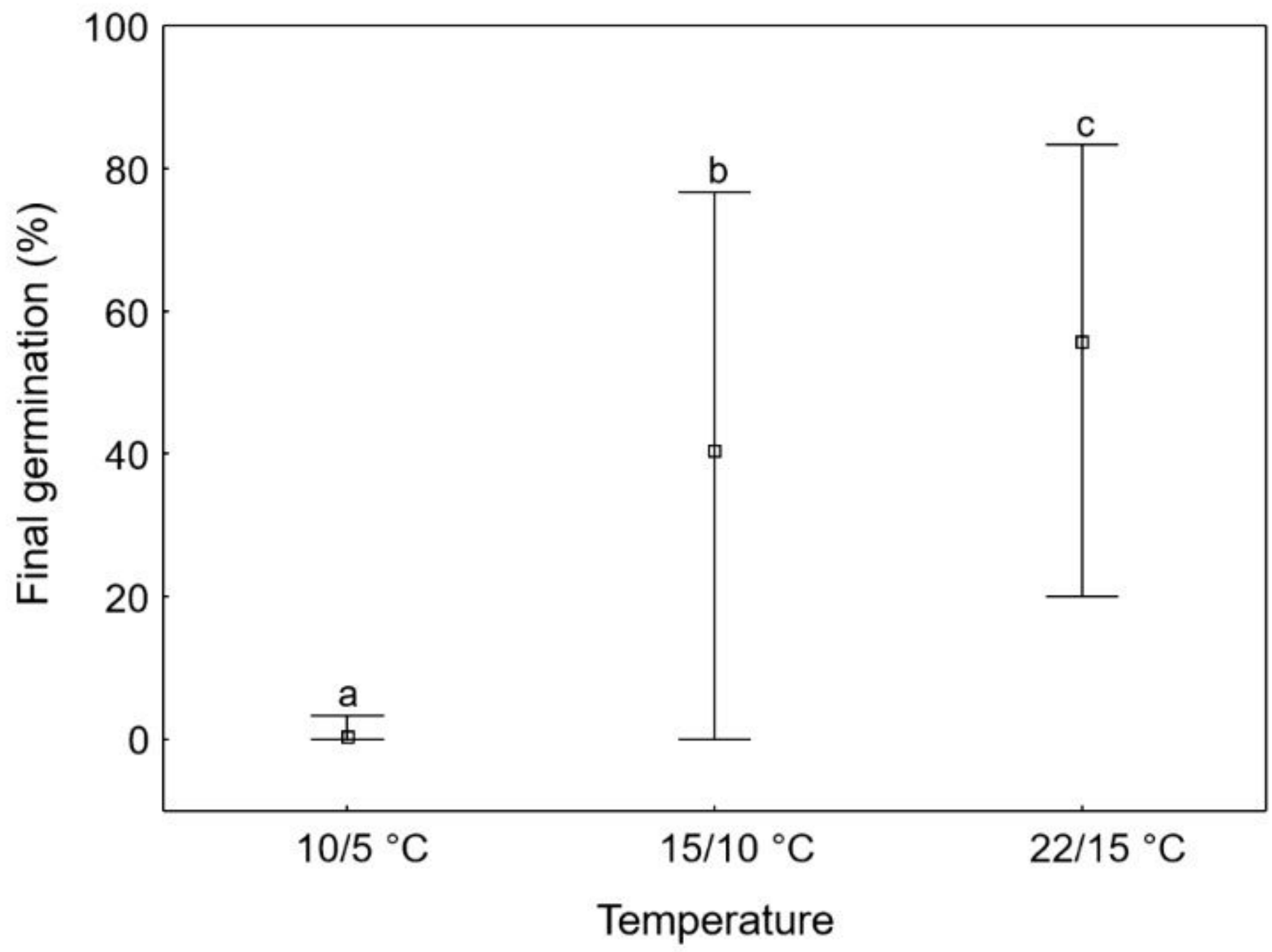

Figure 4

Influence of temperature $\left(10 / 5^{\circ} \mathrm{C}, 15 / 10^{\circ} \mathrm{C}, 22 / 15^{\circ} \mathrm{C}\right)$ on final germination of Stachys byzantina.

Squares $=$ mean of germinated seeds, whiskers $=$ min-max; different letters at the end of each treatment row indicate a statistically significant difference $(P<0.05)$ 
$15 / 10^{\circ} \mathrm{C}$

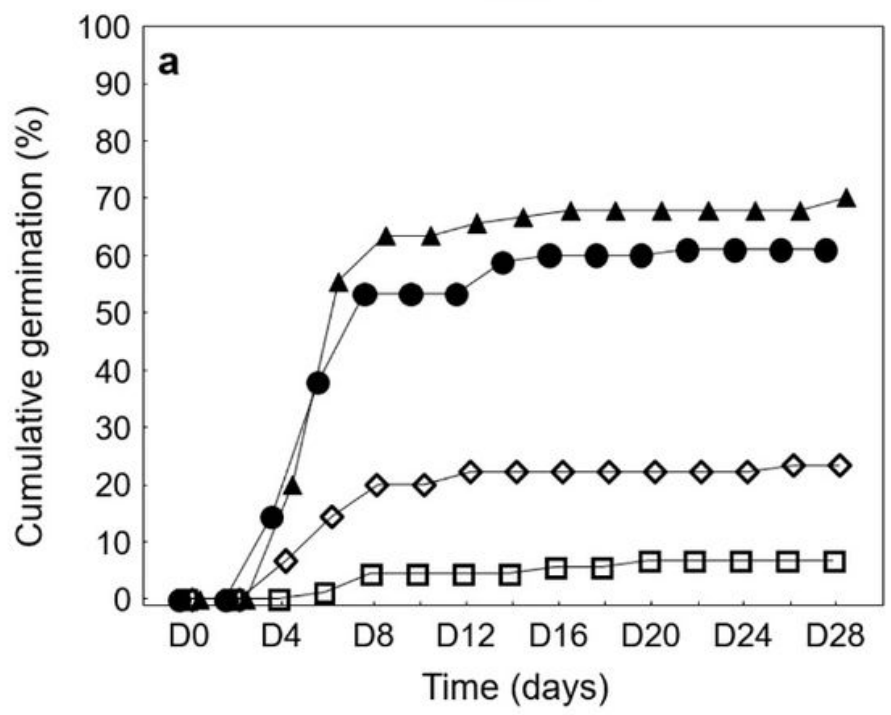

$22 / 15^{\circ} \mathrm{C}$

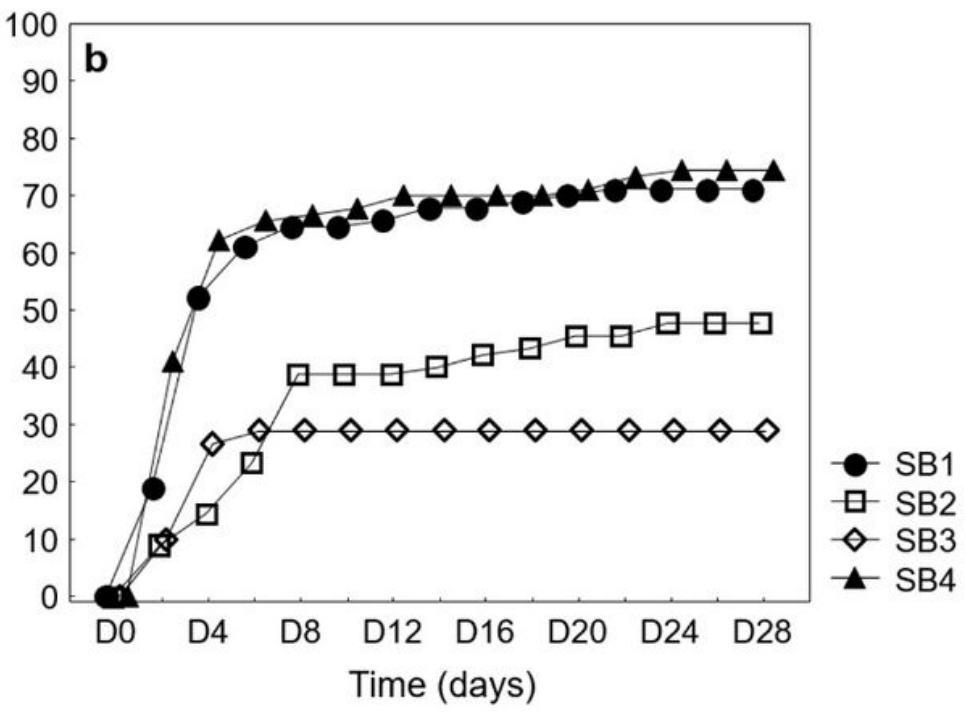

\section{Figure 5}

Time courses of Stachys byzantina seed germination under different temperature regimes $\left(a: 15 / 10{ }^{\circ} \mathrm{C} ; \mathrm{b}\right.$ : $22 / 15^{\circ} \mathrm{C}$ ) (The results for the $10 / 5^{\circ} \mathrm{C}$ temperature regime are not shown as only one seed germinated, giving a final germination of $0.3 \%$ ). SB1-SB4 represent particular localities of sampled populations - see Online Resource table
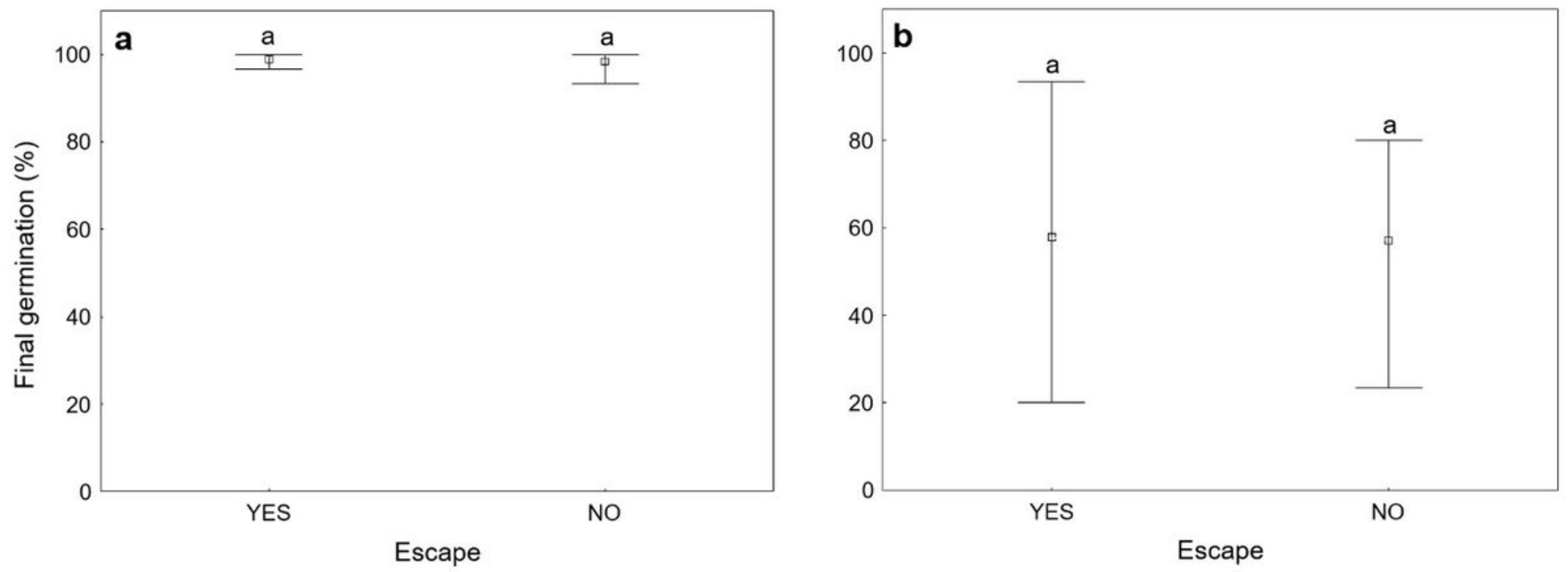

\section{Figure 6}

Analysis of final seed germination between escaping and non-escaping populations of Lychnis coronaria (a) and Stachys byzantina (b). Squares = mean of germinated seeds, whiskers = min-max; the same letters at the end of the treatment row show statistically non-significant differences $(P>0.05)$ 